\section{SOI: 1.1/TAS DOI: 10.15863/TAS International Scientific Journal Theoretical \& Applied Science}

p-ISSN: 2308-4944 (print) e-ISSN: 2409-0085 (online)

Year: 2018 Issue: 09 Volume: 65

Published: 29.09.2018 http://T-Science.org

SECTION 31. Economic research, finance, innovation, risk management. UDC 338:658

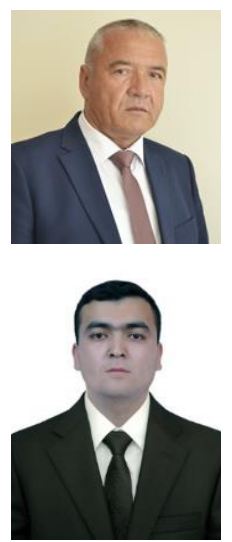

Ilmidin Toshmatovich Yormatov

Candidate of economic sciences, associate professor of the department

"Management"

Ferghana Polytechnic Institute, Uzbekistan

Islombek Shukhratjon ugli Tolibov A third-year student at the Faculty of Management in Production Ferghana Polytechnic Institute, Uzbekistan g7777@mail.ru

\title{
THE CONCEPT OF BUILDING MANAGEMENT BY INFLUENCE OF INNOVATION ON CHANGE OF ORGANIZATIONAL STRUCTURE AND PRODUCTION STRUCTURE OF THE ENTERPRISE
}

Abstract: The article considers the development of the concept of innovation management at an industrial enterprise. The organizational structure of enterprise management is analyzed. A map of the logic of the influence of elements of the organizational structure of management on the factors that determine the production structure of the enterprise is developed. The interrelation between the organizational structure of management and the production structure of the enterprise is studied.

Key words: innovation, innovation strategy, innovation process, organizational structure of the enterprise, matrix.

Language: English

Citation: Yormatov IT, Tolibov IS (2018) THE CONCEPT OF BUILDING MANAGEMENT BY INFLUENCE OF INNOVATION ON CHANGE OF ORGANIZATIONAL STRUCTURE AND PRODUCTION STRUCTURE OF THE ENTERPRISE. ISJ Theoretical \& Applied Science, 09 (65): 256-263.

Soi: http://s-o-i.org/1.1/TAS-09-65-43 Doi: croskef https://dx.doi.org/10.15863/TAS.2018.09.65.43

\section{Introduction}

President of Uzbekistan Shavkat Mirziyoyev, by the decree of September 21, approved the Strategy for Innovative Development of the Country for 20192021 and the Road Map for its implementation [1].

The main goal of the strategy is "development of human capital as the main factor determining the level of the country's competitiveness in the world arena and its innovative progress".

Among the main tasks of the strategy is the entry of Uzbekistan by 2030 into the composition of 50 advanced countries according to the Global Innovation Index rating. Due to the lack of many indicators and "ineffective coordination of work in this direction," the country has not participated in this rating in recent years.

In this connection, the construction of the management of the influence of innovation activity on changing the organizational structure of the enterprise acquires particular urgency. The basis of further methodological developments, obviously, should be the following reasoning. The core of the research is the establishment of the relationship between the organizational structure of management and the production structure when the enterprise carries out innovation activities. Allocation of the named interrelation demands detailed elaboration of investigated structures with a substantiation both external, and internal communications between organizational structure of management and industrial structure of the enterprise. It is important to establish the levels of activities that provide these relationships. The implementation of this approach will allow us to develop qualitative-descriptive and quantitative methods for assessing the degree of this relationship. The presence of such estimates will make it possible to formulate a reasonable idea of the need to improve the quality of the functions, procedures, individual operations performed by the structural elements under study [2].

\section{Research Methodology}

Theoretical and methodological basis of the study were the results of studies of domestic and foreign scholars on issues of strategic and innovation management, innovation management and investments, the economy of the industrial enterprise, legal acts of legislative and executive authorities. When solving tasks used methods of comparative technical and economic analysis, methods of expert 


\begin{tabular}{|c|c|c|c|c|c|c|}
\hline Impact Factor: & $\begin{array}{l}\text { ISRA (India) } \\
\text { ISI (Dubai, UAE } \\
\text { GIF (Australia) } \\
\text { JIF }\end{array}$ & $\begin{array}{l}=1.344 \\
=0.829 \\
=0.564 \\
=1.500\end{array}$ & $\begin{array}{l}\text { SIS (USA) } \\
\text { PИНЦ (Russia) } \\
\text { ESJI (KZ) } \\
\text { SJIF (Morocco) }\end{array}$ & $\begin{array}{l}=0.912 \\
=\mathbf{0 . 1 5 6} \\
=\mathbf{4 . 1 0 2} \\
=\mathbf{2 . 0 3 1}\end{array}$ & $\begin{array}{l}\text { ICV (Poland) } \\
\text { PIF (India) } \\
\text { IBI (India) }\end{array}$ & $\begin{array}{l}=6.630 \\
=1.940 \\
=4.260\end{array}$ \\
\hline
\end{tabular}

estimates, the methods of correlation and regression analysis, concretized in the models of innovation management.

\section{Analysis and Results}

To begin this work should be a decomposition into the constituent elements of the organizational structure of management. All the constituent elements of the organizational structure are closely linked. Moreover, factors that have a direct impact on specific structural component indirectly affect the other structural component, and perhaps all at once. This demonstrates the use of factor research method, including direct analysis, deterministic analysis chain [3]. This study can be conducted with the activation of the matrix, which is clearly demonstrated by the relationship of the structural elements considered by the selection function of each element studied and logical prolongation of the implementation of the functions of other structural elements. A typical form characterized matrix is presented in Table. 1.

Matrix of organizational structure of management

Table 1.

\begin{tabular}{|l|c|c|c|c|}
\hline $\begin{array}{l}\text { Divisions of } \\
\text { management } \\
\text { Functions } \\
\text { of management } \\
\text { of divisions }\end{array}$ & $\begin{array}{l}\text { Marketing } \\
\text { activity }\end{array}$ & $\begin{array}{c}\text { Economic } \\
\text { activity }\end{array}$ & $\begin{array}{l}\text { Construction } \\
\text { activity }\end{array}$ \\
\hline Evaluation of market segmentation & $\mathrm{CY}_{1}^{1}$ & $\cdots$ & $\cdots$ & $\cdots$ \\
\hline Expansion of the market & $\cdots$ & $\mathrm{CY}_{i}^{j}$ & $\cdots$ & $\cdots$ \\
\hline$\ldots$ & $\ldots$ & $\cdots$ & $\cdots$ & $\cdots$ \\
\hline$n$
\end{tabular}

where $I$ - function unit, $I=1 \ldots n$

$j$ - unit organizational structure management, $j=$ $1 \ldots m$

Continuing to set the arguments should be noted that the implementation of innovative activities involved are:

- Marketing activities;

- The planned activities;

- Design activities;

- Technological activities;

- Supply and sales activities;

- Accounting and control activities;

- Activity on staffing.

Direct relationship these activities are not always evident. To control it should detail the specific activities on the functions, procedures, operations and treat them in a methodical, organizational and informational aspects.
For example, continuing to talk about the relationship of innovation activities with other activities, can be identified:

- The formation of consumer preferences (marketing activities);

- Assessment of the market segment (marketing activities);

- Determination of the volume of production (economic activity);

- Determination of the market price (economic activity);

- Design support (engineering activities); activity), etc.

- Technological support (technological

Characteristics of the essence of the production structure of the enterprise, its structural components and the factors that determine it, had already been given. This circumstance is a condition of building the Matrix industrial structure of the enterprise, which is presented in Table.2. 


\begin{tabular}{l|lr|ll|ll} 
& ISRA (India) & $=\mathbf{1 . 3 4 4}$ & SIS (USA) & $=\mathbf{0 . 9 1 2}$ & ICV (Poland) & $=\mathbf{6 . 6 3 0}$ \\
Impact Factor: & ISI (Dubai, UAE) $=\mathbf{0 . 8 2 9}$ & PUHЦ (Russia) $=\mathbf{0 . 1 5 6}$ & PIF (India) & $=\mathbf{1 . 9 4 0}$ \\
& GIF (Australia) & $\mathbf{0 . 5 6 4}$ & ESJI (KZ) & $=4.102$ & IBI (India) & $=\mathbf{4 . 2 6 0}$ \\
& JIF & $=\mathbf{1 . 5 0 0}$ & SJIF (Morocco) & $=2.031$ & & \\
\hline
\end{tabular}

Matrix of industrial structure of the enterprise

Table 2

\begin{tabular}{|l|l|l|l|l|}
\hline $\begin{array}{l}\text { Components of } \\
\text { production structure }\end{array}$ & $\begin{array}{c}\text { Composition } \\
\text { of units } \\
\text { Factors } \\
\text { the industrial } \\
\text { structure }\end{array}$ & $\begin{array}{c}\text { Structure of } \\
\text { production } \\
\text { process }\end{array}$ & $\begin{array}{c}\text { Structure of } \\
\text { technological } \\
\text { process }\end{array}$ & $\begin{array}{c}\text { Structure } \\
\text { of staff }\end{array}$ \\
\hline $\begin{array}{l}\text { Specialization and } \\
\text { cooperation }\end{array}$ & & & & \\
\hline Output & $\mathrm{PC}_{1}^{1}$ & & & \\
\hline Implementation of innovation & & & & \\
\hline Organizational conditions & & $\mathrm{PC}_{q}^{p}$ & & \\
\hline Location & & & & \\
\hline & & & & $\mathrm{PC}_{l}^{k}$ \\
\hline
\end{tabular}

The composition of elements of industrial structure to a certain extent determined by economics and recognized practice. Regarding the factors that determine the type of production structure, as well as the prevalence of some elements over others, it should be noted that their composition is totally defined and the importance of each to highlight the type of structure, too. In this connection it seems to build mutual factorial matrix depending on the basis of specific conditions and involves the method of paired comparisons. Type of such a matrix is shown in Table 3.

Table 3

Matrix of mutual dependence of factors of industrial structure

\begin{tabular}{|c|c|c|c|c|c|}
\hline Factors & $\begin{array}{c}\text { Specialization } \\
\text { and } \\
\text { cooperation }\end{array}$ & $\begin{array}{l}\text { Production } \\
\text { volume }\end{array}$ & \begin{tabular}{|} 
Implementation \\
of innovation
\end{tabular} & $\begin{array}{l}\text { Organizational } \\
\text { conditions } \\
\text { (environment) }\end{array}$ & $\begin{array}{l}\text { Location of } \\
\text { businesses }\end{array}$ \\
\hline $\begin{array}{l}\text { Specialization } \\
\text { and } \\
\text { cooperation }\end{array}$ & & + & - & - & + \\
\hline $\begin{array}{l}\text { Production } \\
\text { volume }\end{array}$ & + & & + & + & - \\
\hline $\begin{array}{l}\text { Implementation } \\
\text { of innovation }\end{array}$ & - & + & & + & - \\
\hline $\begin{array}{l}\text { Organizational } \\
\text { conditions }\end{array}$ & - & + & + & & + \\
\hline $\begin{array}{l}\text { Location of } \\
\text { businesses }\end{array}$ & + & - & - & + & \\
\hline
\end{tabular}

Research presented in the table of factors is extremely important due to the fact that their expression determines the change in the components of the production structure, gives an answer to the question - how they are changed - and all in full or only some of them [4]. Development of the answer to this question requires consideration of the relationship of each of the management structure, the factors determining the industrial structure and components of the production structure. Of course, the answer to this question, it is desirable to quantify.

However, quantitative assessment should precede quality represented by the structural and morphological matrix, reflecting the dependence of the investigated. Clearly, a qualitative assessment can be made through the development of "logic Maps influence elements of the organizational structure of management factors causing production structure of the enterprise and its components" exemplary form of which is shown in Table 4. 


\begin{tabular}{l|lr|ll|ll} 
& ISRA (India) & $=\mathbf{1 . 3 4 4}$ & SIS (USA) & $=\mathbf{0 . 9 1 2}$ & ICV (Poland) & $=\mathbf{6 . 6 3 0}$ \\
Impact Factor: & ISI (Dubai, UAE) $=\mathbf{0 . 8 2 9}$ & PUHЦ (Russia) $=\mathbf{0 . 1 5 6}$ & PIF (India) & $=\mathbf{1 . 9 4 0}$ \\
& GIF (Australia) & $\mathbf{0 . 5 6 4}$ & ESJI (KZ) & $=4.102$ & IBI (India) & $=\mathbf{4 . 2 6 0}$ \\
& JIF & $=\mathbf{1 . 5 0 0}$ & SJIF (Morocco) & $=2.031$ & & \\
\hline
\end{tabular}

Table 4

Map Logic elements influence on the organizational structure of management factors causing production structure of the enterprise and its components

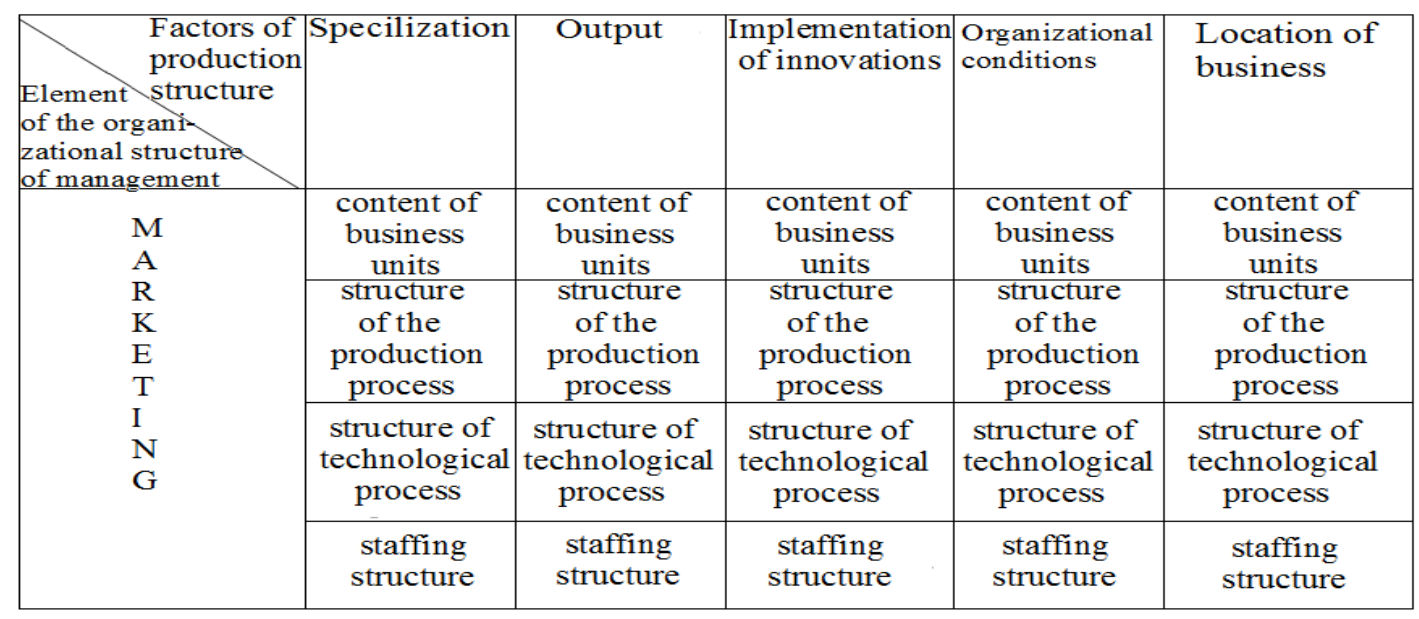

Regarding the maps presented in the table can be assumed that these maps should be prepared for each independent type of work, procedures, processes carried out in the framework of the organizational structure of each element of management. The appendix contains these types of cards for some controls. We should think about technology generalization detailed information on types of work, procedures, processes, related to a specific element of the organizational structure of management. It seems that is not always the blocks of the table will be filled, and this intensifies the need to develop a mechanism for summarizing the title. At the same time we should not exclude a situation where you can stop for engagement only of detailed data.

Classically made five factors that determine the type of production structure and evaluate the role of its components. The composition of these factors has repeatedly called in and submitted to the card (tab. 5). Obviously, these same factors determine the organizational structure and change management. Most likely, the mechanism of the effect of each factor on changing the organizational structure of management and production structure of the enterprise is identical. This circumstance, as well as taking into account the conditions of the problem, allow as a researched factor accept innovation, and, more particularly, innovation.

Table 5.

Map logic influence the organizational structure of management factors causing production structure of the enterprise and its components

\begin{tabular}{|c|c|c|c|c|c|c|c|c|}
\hline \multicolumn{4}{|c|}{$\begin{array}{l}\text { Factors of } \\
\text { production } \\
\text { structure }\end{array}$} & Specilization & Output & $\begin{array}{l}\text { Implementation } \\
\text { of innovations }\end{array}$ & $\begin{array}{l}\text { Organizational } \\
\text { conditions }\end{array}$ & $\begin{array}{l}\text { Location of } \\
\text { business }\end{array}$ \\
\hline \multirow{4}{*}{$\begin{array}{l}\text { P } \\
\text { L } \\
\text { A } \\
\text { N } \\
\mathrm{N} \\
\mathrm{I} \\
\mathrm{N} \\
\mathrm{G}\end{array}$} & \multirow{4}{*}{$\begin{array}{l}\mathrm{O} \\
\mathrm{R} \\
\mathrm{G} \\
\mathrm{A} \\
\mathrm{Z} \\
\mathrm{A} \\
\mathrm{T} \\
\mathrm{I} \\
\mathrm{O} \\
\mathrm{M}\end{array}$} & \multirow{4}{*}{$\begin{array}{l}\mathrm{C} \\
\mathrm{O} \\
\mathrm{N} \\
\mathrm{T} \\
\mathrm{R} \\
\mathrm{O} \\
\mathrm{L}\end{array}$} & \multirow{4}{*}{$\begin{array}{l}\mathrm{P} \\
\mathrm{R} \\
\mathrm{O} \\
\mathrm{V} \\
\mathrm{I} \\
\mathrm{S} \\
\mathrm{I} \\
\mathrm{O} \\
\mathrm{N}\end{array}$} & $\begin{array}{c}\text { content of } \\
\text { business } \\
\text { units } \\
\end{array}$ & $\begin{array}{c}\text { content of } \\
\text { business } \\
\text { units }\end{array}$ & $\begin{array}{c}\text { content of } \\
\text { business } \\
\text { units }\end{array}$ & $\begin{array}{c}\text { content of } \\
\text { business } \\
\text { units }\end{array}$ & $\begin{array}{c}\text { content of } \\
\text { business } \\
\text { units } \\
\end{array}$ \\
\hline & & & & $\begin{array}{c}\text { Structure of } \\
\text { the production } \\
\text { process }\end{array}$ & $\begin{array}{l}\text { Structure of } \\
\text { the production } \\
\text { process }\end{array}$ & $\begin{array}{l}\text { Structure of } \\
\text { the production } \\
\text { process }\end{array}$ & $\begin{array}{l}\text { Structure of } \\
\text { the production } \\
\text { process }\end{array}$ & $\begin{array}{c}\text { Structure of } \\
\text { the production } \\
\text { process }\end{array}$ \\
\hline & & & & $\begin{array}{l}\text { structure of } \\
\text { technological } \\
\text { process }\end{array}$ & $\begin{array}{l}\text { structure of } \\
\text { technological } \\
\text { process }\end{array}$ & $\begin{array}{l}\text { structure of } \\
\text { technological } \\
\text { process }\end{array}$ & $\begin{array}{l}\text { structure of } \\
\text { technological } \\
\text { process }\end{array}$ & $\begin{array}{c}\text { structure of } \\
\text { technological } \\
\text { process }\end{array}$ \\
\hline & & & & $\begin{array}{l}\text { staffing } \\
\text { structure }\end{array}$ & $\begin{array}{l}\text { staffing } \\
\text { structure }\end{array}$ & $\begin{array}{l}\text { staffing } \\
\text { structure }\end{array}$ & $\begin{array}{l}\text { staffing } \\
\text { structure }\end{array}$ & $\begin{array}{l}\text { staffing } \\
\text { structure }\end{array}$ \\
\hline
\end{tabular}

In solving the problem of the development of the ideology of the exclusive place is a tricky question about the point or points of contact of the organizational structure of management and production structure. The tricky issue is that the wellknown data structure and all absolutely convinced 


\begin{tabular}{|c|c|c|c|c|c|c|}
\hline Impact Factor: & $\begin{array}{l}\text { ISRA (India) } \\
\text { ISI (Dubai, UAE } \\
\text { GIF (Australia) } \\
\text { JIF }\end{array}$ & $\begin{array}{l}=1.344 \\
=0.829 \\
=0.564 \\
=1.500\end{array}$ & $\begin{array}{l}\text { SIS (USA) } \\
\text { PИНЦ (Russia) } \\
\text { ESJI (KZ) } \\
\text { SJIF (Morocco) }\end{array}$ & $\begin{array}{l}=0.912 \\
=0.156 \\
=4.102 \\
=2.031\end{array}$ & $\begin{array}{l}\text { ICV (Poland) } \\
\text { PIF (India) } \\
\text { IBI (India) }\end{array}$ & $\begin{array}{l}=6.630 \\
=1.940 \\
=4.260\end{array}$ \\
\hline
\end{tabular}

that there is a connection between them, but both at once, hold the line, reflecting this relationship is not possible. The reason for this is the need to solve the problem from the point of release of the totality of the elements of each of the structures and the establishment of the logic operation. Such an approach would panoramically observe the implementation of innovation in enterprises of all hierarchies.

The first element of the management structure in contact with the innovation, it should be recognized across the spectrum of marketing trends, procedures, operations. Marketing allows you to select innovative products that are in demand, set the preferences of consumers with respect to product innovation, to evaluate the capacity of the market. In fact, marketing provides a framework for the activities of other structural elements of the management system. This situation directly affects the design development of the new products, the need for and the possibility of reflection in the product preferences of consumers and market requirements. Proven design should be technologically solved. Regarding her are economical process technology, equipment, form the requirements for staff. The real embodiment of the idea worked in the innovation happening on the stages of organizational support, which selects the organizational charts the development of new products. Obviously, this component of the governance structure determines its direct relationship with the production structure, as it lays the quantitative ratios of the structural composition of the business units [4]. Each unit has a membership in the implementation of the main, auxiliary, service processes. Accordingly, within each group of processes, the technology of their implementation and are selected personnel able to implement innovation. The stated relationship management organizational structure and production structure of the company is shown in Fig. 1.

The nature of innovation, as well as the amount of work that accompany innovation, diversity. With the development of a fundamentally new facility is necessary to fully implement all the work, procedures, operations performed by each unit of the organizational structure and management of the elements of the production structure. In the case where the object to master the slightly different product types (analog), the production of which the company is debugged, it is necessary to establish the amount of work performed by each unit of the organizational structure, and each element of the production structure. In practice, it is necessary to determine the composition and volume of atypical forms of work (AFW) [6].

Implementation of this work requires the predestination of work scope, procedures, operations performed by a specific unit of the enterprise, which, obviously, should be brought up to regimentation. For each type of work necessary to establish the amount of time by direct measurement or expert. 


\begin{tabular}{l|lr|ll|ll} 
& ISRA (India) & $=\mathbf{1 . 3 4 4}$ & SIS (USA) & $=\mathbf{0 . 9 1 2}$ & ICV (Poland) & $=\mathbf{6 . 6 3 0}$ \\
Impact Factor: & ISI (Dubai, UAE) $=\mathbf{0 . 8 2 9}$ & PVH (Russia) $=\mathbf{0 . 1 5 6}$ & PIF (India) & $=\mathbf{1 . 9 4 0}$ \\
& GIF (Australia) & $=\mathbf{0 . 5 6 4}$ & ESJI (KZ) & $=4.102$ & IBI (India) & $=4.260$ \\
& JIF & $=\mathbf{1 . 5 0 0}$ & SJIF (Morocco) $=\mathbf{2 . 0 3 1}$ & & \\
\hline
\end{tabular}

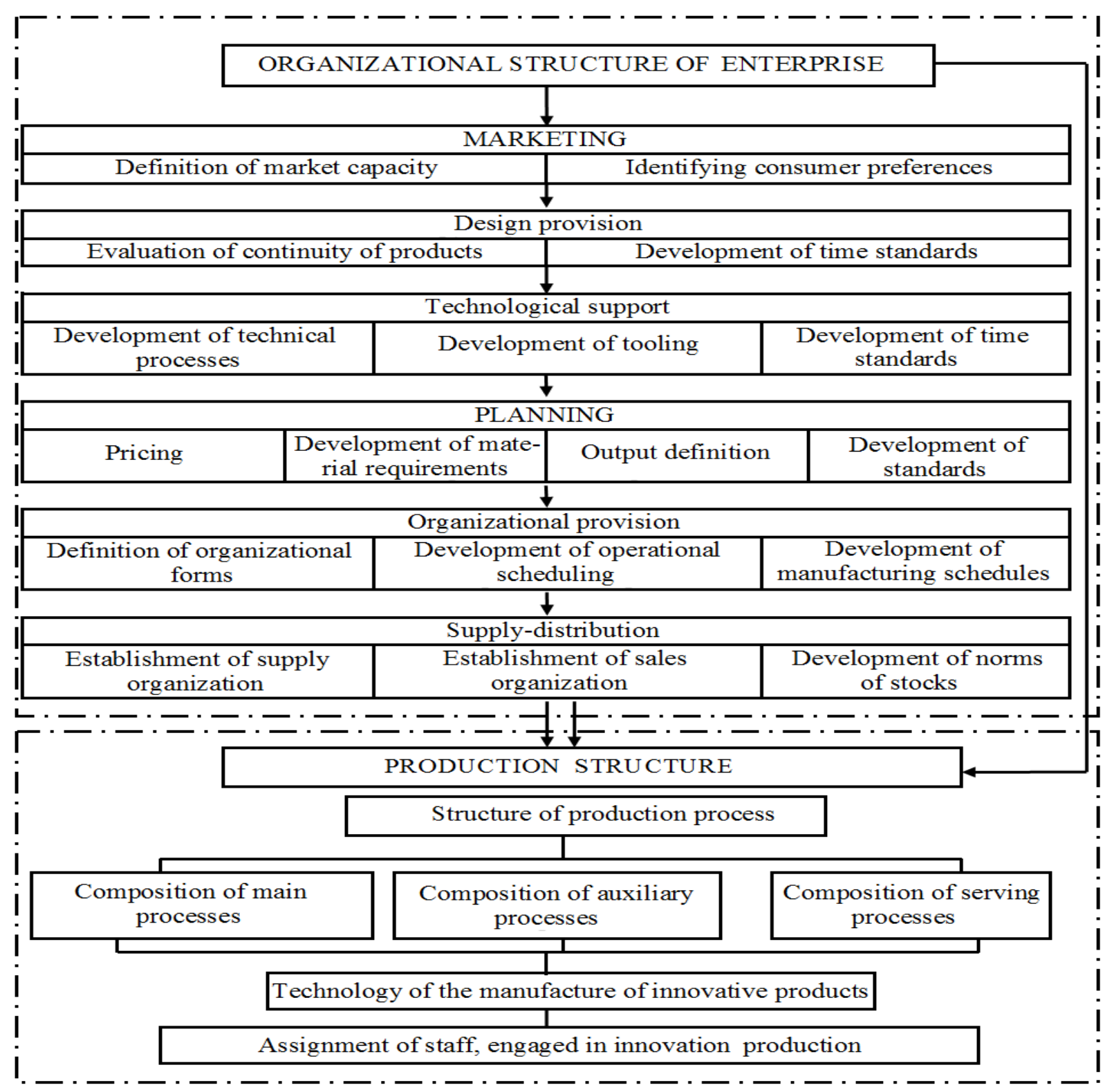

Fig. 1. Relationship management organizational structure and production structure of the enterprise

The composition of atypical types of work stands out by comparison of the work on the development of new products, implemented by each business unit with a typical composition of works brought to regulation. Such a comparison may be nominally by simple comparison required to perform work and is already running, emphasizing identity:

$$
\text { AFW, } \because---->B P i j---->B P i j \text { fact, }
$$

where BP plan and BP fact - executed composition of the work planned and actual; $i$ - operation; $j$ - unit

There are two possible solutions represented by the equation:

1. Compliance with the planned composition of the actual work, in this case, the innovation development, has manufactured products:
BPijplan=BPijfact,

(2)

2. The difference between the planned amount of work from the previously performed for the development of the product:

\section{BPijplan $\neq$ BPijfact,}

where $\Delta i j$ - part of $i$ operations to be master in the $j$ th unit for the manufacture of innovative products.

This development is most likely due to the fact that with the advent of the need for additional, new types of work generated confidence in the development of innovative products is.

Identification of atypical forms of work, as well as the immediate elaboration of a fundamentally new product for the company, in essence aims to establish 


\begin{tabular}{|c|c|c|c|c|c|c|}
\hline Impact Factor: & $\begin{array}{l}\text { ISRA (India) } \\
\text { ISI (Dubai, UAE } \\
\text { GIF (Australia) } \\
\text { JIF }\end{array}$ & $\begin{array}{l}=1.344 \\
=0.829 \\
=0.564 \\
=1.500\end{array}$ & $\begin{array}{l}\text { SIS (USA) } \\
\text { PИНЦ (Russia) } \\
\text { ESJI (KZ) } \\
\text { SJIF (Morocco) }\end{array}$ & $\begin{array}{l}=0.912 \\
=\mathbf{0 . 1 5 6} \\
=\mathbf{4 . 1 0 2} \\
=\mathbf{2 . 0 3 1}\end{array}$ & $\begin{array}{l}\text { ICV (Poland) } \\
\text { PIF (India) } \\
\text { IBI (India) }\end{array}$ & $\begin{array}{l}=6.630 \\
=1.940 \\
=4.260\end{array}$ \\
\hline
\end{tabular}

the amount of work to be undertaken. It should be remembered that the need to establish and scope of work and the complexity of their implementation [7]. Presenting practical complexity of the task laid down, we think it necessary to develop a position on the choice of the method of solving it. It is clear that the most appropriate should be recognized expert methods. They should be the basis for the development of methods of this study [8,9].

The above arguments, which predicts the course of this study and its logic is the concept and are presented in Fig. 2.

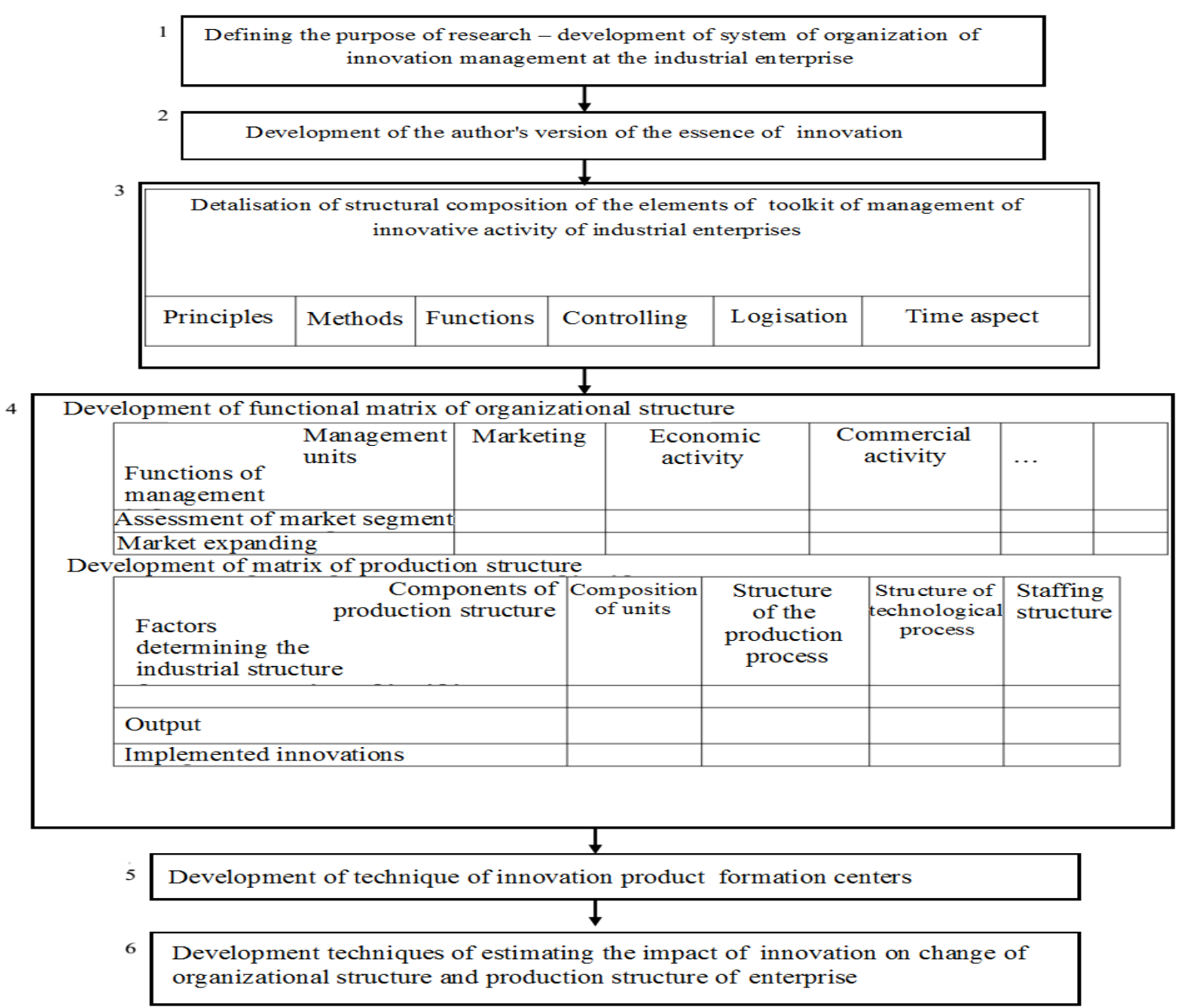

Fig. 2. The structural representation of concept of research

\section{Conclusion}

All units, reflecting the structural representation of the concepts presented in the figure, up the course of the study. The theoretical aspects of the study have already been reflected in the text of the work [10]. It should be noted that they are the basis of the decision of applied tasks of this work. These include:

- method of forming innovative food centers due to the conditions and feasibility of the latter;
- method of estimating the impact of innovation to change the organizational structure of management and production structure of the company, which represents a logical continuation of the above techniques.

It seems that the concept represented by predetermined character further work in this study and its possible results. 


\begin{tabular}{l|lr|ll|ll} 
& ISRA (India) & $=\mathbf{1 . 3 4 4}$ & SIS (USA) & $=\mathbf{0 . 9 1 2}$ & ICV (Poland) & $=\mathbf{6 . 6 3 0}$ \\
Impact Factor: & ISI (Dubai, UAE) $=\mathbf{0 . 8 2 9}$ & PUHL (Russia) $=\mathbf{0 . 1 5 6}$ & PIF (India) & $=\mathbf{1 . 9 4 0}$ \\
& GIF (Australia) & $\mathbf{0 . 5 6 4}$ & ESJI (KZ) & $=\mathbf{4 . 1 0 2}$ & IBI (India) & $=\mathbf{4 . 2 6 0}$ \\
& JIF & $=1.500$ & SJIF (Morocco) & $=\mathbf{2 . 0 3 1}$ & & \\
\hline
\end{tabular}

\section{References:}

1. (2018) On the approval of the strategy of innovative development of the Republic of Uzbekistan for 2019-2021. Decree President of the Republic of Uzbekistan UP-5544 of September 21, 2018. Electronic resource: http://www.lex.uz/ru/pdfs/3913186.

2. Kurpayanidi, K., Muminova, E., \& Paygamov, R. (2015). Management of innovative activity on industrial corporations. Monograph. LAP LAMBERT Academic Publishing. Germany.

3. Margianti, E. S., Ikramov, M. A., Abdullaev, A. M., Kurpayanidi, K. I., \& Ashurov, M. S. (2014). Systematical analysis of the position and further development of Uzbekistan national industry in the case of economic modernization. Monograph. Indonesia, Jakarta. Indonesia, Jakarta, Gunadarma Publisher.

4. Semenkin, Ye. S., \& Kleshkov, V. M. (2006). Modeli i algoritmy raspredeleniya obshchikh resursov pri upravlenii innovatsiyami restrukturirovannogo mashinostroitel'nogo predpriyatiya. Problemy mashinostroyeniya i avtomatizatsii, (3), 24-30.

5. Ellison, N. B., Gibbs, J. L., \& Weber, M. S. (2015). The use of enterprise social network sites for knowledge sharing in distributed organizations: The role of organizational affordances. American Behavioral Scientist, 59(1), 103-123.
6. Gureva, M. A., Kirillov, A. V., Vinichenko, M. V., Melnichuk, A. V., \& Melnychuk, Y. A. (2016). Management of innovations and innovative process: concept, essence, classification and diffusion. International review of management and marketing, 6(6S), 147-153.

7. Bromiley, P., McShane, M., Nair, A., \& Rustambekov, E. (2015). Enterprise risk management: Review, critique, and research directions. Long range planning, 48(4), 265276.

8. Epifanova, T., Romanenko, N., Mosienko, T., Skvortsova, T., \& Kupchinskiy, A. (2015). Modernization of institutional environment of entrepreneurship in Russia for development of innovation initiative in small business structures. European Research Studies, 18(3), 137.

9. Foss, N. J., \& Saebi, T. (2017). Fifteen years of research on business model innovation: How far have we come, and where should we go? Journal of Management, 43(1), 200-227.

10. Bustinza, O. F., Bigdeli, A. Z., Baines, T., \& Elliot, C. (2015). Servitization and competitive advantage: the importance of organizational structure and value chain position. ResearchTechnology Management, 58(5), 53-60. 